Carrière "raised several garden forms" of radish " of various colours from the seed of the wild species ( $R$. raphanistrum); and found that they produced the long form in a light soil, and the turnip-rooted form in a stit. soil. A similar result has occurred with carrots. By selecting seed from plants having the best formed roots, these " (characters) "have become fixed and hereditary" (" How to Study Wild Flowers," 1902).

(2) I was delighted in the early summer by the marvellous skill and intelligence exhibited by some collies in the annual sheep-dog trials, which reveal apparently much more than the results of individual training. I have lately seen a pack of hounds streaming over the same country after a fox. The hound (triste lupus in stabulis) would make an indifferent sheep-dog, and the master who brought a pack of collies to a meet would provide some novel sport for the field. The collie is trained individually, but he has an inherent, if not inherited, aptitude, just as the foolishly good-natured hound puppy who is "put out to nurse" in his earlier days readily learns his work when he joins the pack. Further than this, an ordinary dogshow displays group peculiarities in different types of dog. The fox-terriers snarl savagely at each other, the greyhounds and their allies bark and yelp continuously, and appear as though on the verge of neurotic insanity, while the foxhounds lie and appear to drowse silently with a well-bred air of tolerant boredom that forms a curious contrast to the howling multitudes around them. Yet they are all dogs, and have reached their typical specialisation by characters acquired in some way.

If we are forbidden to believe that acquired characters are hereditary, what is the explanation of the seed of the "student" parsnip and the "turnip" radish coming true to type, and why does a collie drive sheep and a hound give tongue at the scent of a fox? Is it suggested that in the "germ plasm" of the wild dog all these special qualities are already involved, just as the digestive peptones gathered functionally and localised in the leaves of Dionæa and Drosera are found wardering aimlessly and to no purpose in some fruit trees? If so, what is the nature of the directive impulse that localises these characteristics in hound, collie, Drosera, and radish immediately fertilisation takes place? And again, how does the "peppered moth" contrive to appear in the black country hatched with sooty wings that harmonise with the now smoke-stained bark whereon he must rest? The whole subject of mimicry seems to be involved, and if your reviewer is right (NATURE, January 2, p. 193) in noting with "a sense of weariness mingled with surprise the appearance of a book on the transmission of acquired characters," it is quite certain that the "isolated biologists, and whole hosts of medical men who still hold the belief that acquired characters are transmitted "would regard it as a great boon if he would tell those who "make him tired" what are the conclusions apparently already established by "the modern, and still infant, science of heredity" that will satisfactorily account for such facts as I have ventured to state.

It will hardly do to say that in one sense the problem is " as unreal as the question of the apple dumpling which puzzled one of the Georges, because the characters of an organism do not get into its germ-cells any more than the apple gets into its crust, for both the germ-cells and the apple were there all the time." "One of the Georges" would doubtless have been grateful for a little culinary instruction, just as "whole hosts" of somewhat puzzled people with open minds would be honestly sincerely grateful for a definite explanation from " the infant science of heredity" as to how the sheep-driving impulse really got into the sheep-dog. For "nature" is more luminous than a text-book.

Waterstock, Oxford, January 3 .

The Diamantiferous Rock of Kimberley.

My friend, Dr. Hatch, is not quite correct in stating (January $9, p .225$ ) that $I$ was led to dissent from the late Prof. Carvill Lewis's view that the diamantiferous rock of Kimberley was a volcanic peridotite "by a microscopic examination made in 1899 of specimens from the Newlands Mines", (Proc. Rov. Soc., lxv., 1899, p. 223).
Four years earlier I expressed the opinion that this rock was a breccia, and that the diamonds, with other conspicuous minerals, were not formed in situ (Geol. Mag., 1895, p. 50o). This belief was strengthened rather than shaken by editing Prof. Carvill Lewis's notes and examining his specimens ("The Genesis of the Diamond"), and was expressed yet more decidedly later in 1897 after examining another series of specimens from Kimberley (see Geol. Mag., I897, p. 501). To discuss the "magma", and " concretion" hypothesis would be out of place here, but clsewhere I may have something to say on those subjects.

T. G. BONNEY,

Musical Sands.

Mr. Carus-Wilson's failure (January 9, p. 222) to obtain sounds, from "millet seed" sand of highly spherical grains puts a difficulty in the way of the suggestion made in "Sound" by Poynting and Thomson, though I do not think that it finally disposes of it.

I have not been able to follow the friction explanation as given by $\mathrm{Mr}$. Carus-Wilson (Nature, August 6, I891) and $I$ write in the hope that he may give more detail as to the moving system which produces the musical note It appears probable that the musical sounds excited in a body by friction are due to the natural vibrations of that body. Obviously the grains of sand are far too small to give the notes heard. I suppose that the fundamental period is of the order of the time taken by an elastic wave to travel half round the grain. With elastic moduli of the order $10^{11}$ and density $2 \frac{1}{2}$, the fundamental frequency would be not less than $10^{6}$. What system does the friction set in vibration?

The University, Birmingham, January II.

IN Nature of January 9 (p. 222) Mr. Carus-Wilson's letter asks for further details of the "singing sands" that I exhibited to the Physical Society. I am able to give the mineralogical description, by $\mathrm{Mr}$. A. J. Maslen, of the Maine sand from Mareen's beach, near Small Point, at the entrance of the Kennebec River.

A subangular sand very free from very small grains. Clean

Quartz. Principal constituent. As perfectly colourless grains showing conchoidal fracture (rock-crystal) and as more or less coloured grains of quartzite.

Muscovite Mica. Small quantity. Flakes.

Glauconite. Dark green grains, many of fairly large size. Almost black.

Topaz (?) Square pieces due to cleavage. Yellow.

Opaque white, substance. (Felspar?)

Magnetite. Small grains. Rare.

The other specimens of sands were very similar to tha rom Maine.

South-Western Polytechnic, Chelsea, S.W., January 13 .

\section{Intensity of Spectrum Lines.}

VERY little attention has been paid in the past to the accurate measurement of the optical intensity of spectral lines in vacuum tubes under different conditions, probably on account of the considerable experimental difficilties. Hence I may, perhaps, be allowed to indicate a relation I have obtained between the optical intensity, current strength, and pressure of the glowing gas. Throughout the whole experimental range, using the so-called "electrodeless" tube-with wholly external mercury electrodes, when the current is of a slowly oscillating character-the optical intensity, with an end-on tube, is accurately proportional to the readings of a thermo-galvanometer in series, and over a more limited range of measurement, at constant current, is inversely proportional to the pressure of the gas.

In other words, the intensity is proportional to $\lambda \int c^{2} \delta t$, where $\lambda$ is the mean free path.

Measurements on the monatomic gases are now in progress, and it is intended later to investigate the influence of temperature.

University College, London, W.C.
A. D. Cowper.

No. 1994 YOL 77] 